\title{
Methods Analysis for assessing the effectiveness of the air exchange organization
}

\author{
Volodymyr Dovgalyuk ${ }^{1}$, Anna Sitnicka ${ }^{2}$, Mykola Tereschuk ${ }^{3}$ \\ Kyiv National University of Construction and Architecture \\ 31, Prosp. Povitroflotsky, Kyiv, Ukraine, 03037 \\ ${ }^{1}$ 2280170@ukr.net, orcid.org/0000-0002-4836-5354 \\ 2sit_ann@ukr.net, orcid.org/0000-0003-1074-5762 \\ 3nikolatereschuk@gmail.com, orcid.org/0000-0002-4444-3677
}

DOI: $10.32347 / 2310-0516.2018 .11 .103-111$

Summary. This article provides the review of scientific literature on the estimation of ventilation systems efficiency. It has been shown that energy efficiency requirements are becoming increasingly important for building microclimate systems. The operating costs of ventilation and air conditioning systems in some buildings can reach $50 \%$ of the total cost. The state of the airspace directly affects the health of people and the productivity of their work. Therefore, the question of assessing the quality of ventilation and air conditioning systems at the design stage is relevant.

There are different approaches to determining the efficiency of air exchange in the room. Modern approaches to assessing the effectiveness of ventilation in Ukraine, the EU and the US are significantly different, requiring an analysis and understanding of the advantages and disadvantages of each. The evaluation of the air exchange efficiency using the $K_{L}$ coefficient is based on the construction of an approximate mathematical model of heat and mass transfer processes in the room. The methods of its analytical determination are developed.

However, the coefficient KL does not allow to evaluate the efficiency of ventilation systems with variable air flow, the use of $K_{L}$ is problematic for height uniform distribution of temperature in the room. European approaches to assessing the effectiveness of ventilation are based on the assessment of the average $\mathrm{CO} 2$ concentration in the room or the average concentration of $\mathrm{CO} 2$ in the service area. The concept of air "age" is also used. It is impossible to estimate the effectiveness of ventila-

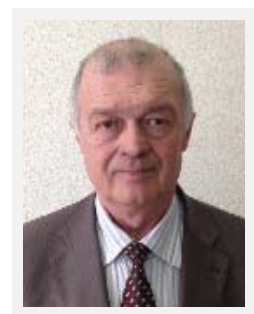

\section{Volodymyr Dovgalyuk}

Associate Professor of the

Department of Heat and

Ventilation, Ph.D., Ass. Prof.

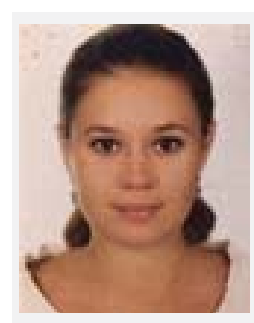

Anna Sitnicka

Postgraduate of the Department

of Heat and Ventilation

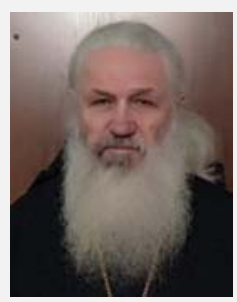

Mykola Tereschuk

Postgraduate of the Department

of Heat and Ventilation

tion by the formation of temperature and humidity fields indoors according to European methods.

US standards use indoor air quality and energy consumption to compare $\mathrm{E}_{\mathrm{vz}}$ ventilation efficiency. However, the determination of the efficiency of the air distribution $E_{z}$, on which the value of $E_{v z}$ depends, is carried out in a simplified manner. All existing techniques do not allow to determine the intensity of air turbulence in the room. For this purpose, we need to develop criteria for assessing the effectiveness of ventilation, which takes into 
account the majority of factors that affect the microclimate in the room.

Key words. Energy efficiency, ventilation systems, air conditioning, coefficient, flow rate, air "age", American methodology, VAV-systems, single-channel systems, cold air supply.

\section{FORMULATION OF THE PROBLEM}

The issue of assessing the energy efficiency of a building engineering system is becoming increasingly important. In some buildings, operating costs for systems of ventilation (SV) and air conditioning (HVAC) can reach 50\% of total costs. Therefore, the issues of quality of assessment and air conditioning at the design stage are relevant.

There are different approaches to determining the efficiency of air exchange in the room. Modern approaches to assessing of effectiveness of SV and HVAC in Ukraine, are significantly different from EU countries and the USA, which requires analysis and understanding of the advantages and disadvantages of each.

\section{ANALYSIS OF RECENT RESEARCH AND PUBLICATIONS}

In the domestic practice of designing, an assessment of the air exchange organization effectiveness is carried out using one of the following techniques:

The "integral" method [1, 2, 3] is based on the compilation of an approximate mathematical model of heat and mass transfer processes in the room and the determination of the air exchange coefficient $K_{L}$;

The "power" method [4], which uses the ratio of the energy of the fuel and heat jets to characterize the distribution of harm in the premises;

The "statistical" method [5] allows us to estimate the unevenness of the field of temperature and velocity in a room formed by the air distribution system and is characterized by the law of distribution and the mean square deviation $\sigma$.

An American approach to assessing the ventilation systems effectiveness is described in ASHRAE (American Society for Heating, Refrigerating and Air Conditioning Engineers) standards [6]

European norms determine the effectiveness of the correlation between concentrations of carbon dioxide pollution in the tidal and exhaust air [7]

The energy efficiency of the SV and HVAC systems is largely determined by the organization of air exchange, which in turn depends on the type and location of sources of pollution, the design features of the premises and, above all, the air distribution system.

Formulation of the problem. Comparative analysis of the current criteria is conducted in this article for assessing the effectiveness of SV and HVAC used in domestic, American and European approaches in order to identify the advantages and disadvantages of each and to develop a modern approach that will take into account all factors affecting efficiency.

Main part. The task of improving the energy efficiency of ventilation and air conditioning systems is directly related to the efficiency of the use of air supplied to the premises. There are different approaches to determining the efficiency of air exchange in the room.

The "integral" method uses the coefficient of air exchange $K_{L}$, which led N.S. Sorokin [8] to evaluate the efficiency of the use of tidal air.

The coefficient of air exchange $K_{L}$ is a temperature simplex, which is known to be used in determining the amount of inflow air supplied to the room (air exchange), and the assessment of the efficiency of air distribution systems. Depending on the task, the air exchange rate is determined [9] by the temperature $t_{l}$ of the exhaust air

$$
K_{L}=\left(t_{l}-t_{i_{n}}\right) /\left(t_{w z}-t_{i n}\right),
$$

or by the average temperature $t_{l, \text { sum }}$ of the exhaust air of local and general exchange ventilation systems

$$
K_{L, \text { sum }}=\left(t_{l, \text { sum }}-t_{i_{n}}\right) /\left(t_{w z}-t_{i n}\right),
$$


or by the weighted average temperature of the air over the zones of the room:

$$
t_{l, \text { sum }}=\sum t_{i} \cdot G_{l, i} / \sum G_{l, i}
$$

The coefficient $K_{L}$ is used to calculate the air exchange in the room. For example, when calculating the excess of explicit heat:

$$
L_{0}=L_{w z}+\frac{3.6 \cdot Q+c \cdot L_{w z} \cdot\left(t_{w z}-t_{i n}\right)}{c \cdot K_{L}\left(t_{w z}-t_{i n}\right)}
$$

where: $L_{o}$ - amount (flow) of the inflow air, $\mathrm{m}^{3} / \mathrm{h} ; L_{w z}-$ flow rate of air removed from the working area by local suction pumps, common ventilation and technological needs, $\mathrm{m}^{3} / \mathrm{h}$; $t_{i n}, t_{w z}, t_{l}-$ the air temperature is accordingly fed into the room, in the working area, removed from the outside of the working area, ${ }^{\circ} \mathrm{C} ; Q$ - excessive apparent heat flow in the room, $\mathrm{W} ; c$ - air heat capacity, $\mathrm{kJ} /\left(\mathrm{m}^{3} \cdot \mathrm{s}\right)$.

For the theoretical estimation of the air exchange rate, the use of an approximate mathematical model of heat and mass transfer processes in the premises is proposed in the works [10] based on the balance equations. The development of the model consists of four stages:

1. Determination of the calculation scheme of heat and mass exchange in the room with the allocation of characteristic volumes and surfaces involved in heat and mass transfer, and with the designation of heat flows and air mass.

2. Equations formation of heat and mass conservation for all characteristic volumes and surfaces with addition of other equations of connection if possible.

3. Reduction of balance equations to the calculation form.

4. Setting a specific problem and solving a system of equations.

The approximate mathematical model allows to distinguish the main factors that determine the efficiency of the air exchange, evaluate their impact and optimize the valuesof controlled factors (air flow and temperature, type of steams, etc.).
It is generally accepted to evaluate the efficiency of air supply by the magnitude of the air exchange rate: the more $K_{L}$ is, the less amount of air supplied to the premises is need. In the result of many years' research, the calculated ratios for finding the air exchange rate $\left(K_{L}\right)$ were obtained for all major methods of supplying air to ventilated and air-conditioned rooms $[1,2,3]$

In Pozin work [11] it is suggested to take into account not only the value of $K_{L}$, but also the operating temperature difference:

$$
\Delta t_{w z}=t_{w z}-t_{i n}
$$

to estimate the air exchange efficiency. At the same time, the value of the working temperature difference can be varied and determined by the system of air distribution. The larger value of the product of this coefficient on the temperature difference magnitude, the more perfect is the organization system of air exchange.

The disadvantages of the "integral" method include the impossibility to determine the effectiveness of SV and HVAC with quantitative regulation, turbulence of air in the working area. The use of a coefficient $K_{L}$ as a criterion for the effectiveness of air exchange, for premises where it is necessary to maintain the same height and humidity (for example, museum rooms), needs to be substantiated.

V.M. Elterman [4] proposed to characterize the processes occurring in the ventilation of rooms with excess heat, criterion $K$, which is derived from the equation that determines the amount of energy dissipating in the air environments of the ventilated space. Dependence obtained:

$$
K=\frac{\vartheta^{3} \cdot c_{\rho} \cdot T_{0} \cdot \rho_{0}}{g \cdot \bar{Q} \cdot l^{2}},
$$

where: $\vartheta$ is the average speed of air outlet from the fuel outlets, $\mathrm{m} / \mathrm{s} ; \rho-$ Indoor air density, $\mathrm{kg} / \mathrm{m}^{3} ; l$-characteristic size, $\mathrm{m}$.

The heat stress of the volume, $\mathrm{W} / \mathrm{m}^{3}$, shows the ratio of energy of the inflow and thermal 
steams. It can be considered as the ratio of kinetic energy, which dissipates in the mass of the air, to the energy that spends against gravity. In the work [4] it is shown that the coefficient $K_{L}$ can be expressed by criterion $K$ for a heat-stressed building. The criterion $K$ makes it possible to evaluate the changes in the ratio of conditions in the working zone and in the air to be removed when changing the individual values included in this criterion. However, in addition to the disadvantages of the $K_{L}$ coefficient, criterion $K$ does not take into account the heterogeneity of heat transfer in certain areas of the premises, it can not be applied if the main harmfulness is carbon dioxide $\mathrm{CO} 2$ $[12,13]$. The statistical method allows us to estimate the unevenness of the temperature field $t,{ }^{\circ} \mathrm{c}$; mobility $v, \mathrm{~m} / \mathrm{s}$; relative humidity $\varphi$, which creates an air distribution system in the working area [14]. The unevenness of the field of these parameters may be characterized by the distribution law and the mean square deviation $\sigma$. With some approximation, they adopt a normal law of temperature distribution and indoor air mobility $[15,16,17]$. Under these conditions, deviations within $\pm \sigma$ of the mean value occur at $2 / 3$ points (volume of the working zone), and $\pm 2 \sigma$-approximately $95 \%$ of the points. The disadvantage of the static method for assessing the effectiveness of establishing normative parameters of the air environment in the premises is the need to include experimental data for calculations for each type of air distribution devices that are used.

The European approach to assessing the effectiveness of ventilation is based on two concepts:

- Effectiveness of removing pollutants $\varepsilon_{c}$ as a measure of the removal speed of contaminated air from the premises [18];

- Efficiency of air exchange $\varepsilon_{c}$ as a measure of the rate of air indoors replacement [19] (concept of air "age").

The effectiveness of the removal of pollutants can be determined relative to the average concentration of pollutants in the room:

$$
\varepsilon_{c}=\frac{C_{e}-C_{s}}{C_{\text {mean }}-C_{s}},
$$

Or for the average concentration [21] of pollutants in the service area:

$$
\varepsilon_{c}=\frac{C_{e}-C_{s}}{C_{o z}-C_{s}} .
$$

where: $C_{e}$ - concentration of pollutants in the exhaust air; $C_{s}$ - Is the concentration of pollution in the inflow air; $C_{\text {mean }}-$ is the average value of the concentration of pollutants in the room; $C_{o z}-$ is the average concentration value of contaminants in the service area.

Formula (4) is similar to dependence (1) for determining the coefficient $K_{L}$. Using the criterion of the effectiveness of removing pollutants $C_{c}$ it is impossible to take into account the distribution of its concentration in separate zones of the premises, especially when it is unevenly located in height of the room, for example, as in the Orthodox churches.

The concept of air "age" is based on the determined time of finding the air molecules at a given point. The reference time begins with the supply of air into the room. The average air "age" at a point describes the stationary mode of ventilation and shows the average time air molecules that hit this point spent in the room [22]. Near the exhaust holes, the average air "age" in hours is the magnitude of the inverse multiplicity of air exchange:

$$
\bar{\tau}=V / L,
$$

where: $V$ - volume of the room, $\mathrm{m}^{3} ; L$ - flow rate of air, $\mathrm{m}^{3} / \mathrm{h}$.

Thus, the average air "age" at the point $\bar{\tau}_{\rho}$ is the measure of air quality at the point.

The efficiency of the air exchange $\varepsilon_{a}, \%$, is defined as the ratio of the minimum possible replacement air time in the room [23] $\tau_{r}$, equal to twice the average air "age" in the room $\bar{\tau}$ :

$$
\varepsilon_{a}=\left(\tau_{n} / \tau_{r}\right) \cdot 100=100 \cdot \tau_{n} /(2 \bar{\tau}) .
$$

The local air exchange rate $\varepsilon_{p}^{a}$ characterizes the state of the air environment at a specific point $\mathrm{P}$. The local air exchange rate is the ratio 
of the nominal constant time $\tau$ n to the average air "age" $\tau_{\rho}$ at the point $P$ :

$$
\varepsilon_{\rho}^{a}=100 \tau_{n} / \tau_{\rho}
$$

The air "age" is a factor in assessing the ability of the ventilation to dilute $\mathrm{CO} 2$ and other gases to the maximum allowable concentration. It is not possible to estimate the effectiveness of ventilation on the formation of temperature and humidity parameters of the air environment in the room [24].

The American methodology [6] for calculating efficiency is based on the concept of the effectiveness of ventilation of the zone.

The rate of air exchange is determined by the summation of the need to supply fresh air directly to human breathing and to dilute the harm done in the room.

\section{THE ORDER OF CALCULATION OF VAV-SYSTEMS ACCORDING TO ASHRAE 62.1-2016}

Firstly, the air flow rate for the working area is determined by the formula:

$$
V_{b z}=R_{p} \cdot P_{z}+R \cdot A_{z},
$$

where: $A_{z}$ is the floor area of the zone: the net floor area of the zone, $\mathrm{m}^{2} ; P_{z}$ - number of people in the zone; $R_{p}, R_{a}$ - required external air flow, respectively, per person, and per unit area.

We find the calculated zonal flow of external air next:

$$
V_{o z}=V_{b z} / E_{z}
$$

Efficiency of zonal air supply $\left(E_{z}\right)$ is taken according to Table 1, depending on the scheme of airborne exchange in the room. Exhaust air consumption depends on the type of system:

1) For single-zone systems:

$$
V_{o t}=V_{o z} .
$$

2) For systems that operate without recirculation (100\% external air):

$$
V_{o t}=\Sigma_{\text {allzones }} \cdot V_{o z} \cdot
$$

3) For multi-zonal systems

$$
V_{o t}=V_{o u} / E_{v},
$$

where: $V_{\text {ои }}$ - uncontrolled outdoor air sampling:

$$
V_{\text {ou }}=D \cdot \Sigma_{\text {allzones }} \cdot R_{p} \cdot R_{z} \cdot \Sigma_{\text {allzones }} \cdot R_{a} \cdot A ;
$$

$E_{v}$ - the effectiveness of the ventilation system, determined by the table, depending on the $\operatorname{Mach}\left(Z_{p}\right) ; D$ - change of presence:

$$
D=P_{s} / \Sigma_{\text {allzones }} \cdot R_{z} \text {. }
$$

If the effectiveness of the ventilation system can not be determined from Table 1, the alternative calculation method shown in Annex $\mathrm{A}$ of this standard can be used, where $E_{v}$ is equal to the lowest of the values calculated by the efficiency of the zonal ventilation $E_{v z}$ (efficiency with which the system transfers the outside air from the air outlet to a separate work area).

For single-channel systems:

$$
E_{v z}=1+X_{s}-Z_{p z}
$$

where: $X_{s}$ is the average proportion of external air in the inflow air of a ventilation system operating on several premises; $Z_{p z}$ - the proportion of external air in the inflow air space.

The equation is used for systems where all ventilation air is a mixture of external air and recirculation from one place.

The general case:

$$
E_{v z}=\left(F_{a}+X_{s} \cdot F_{b}-Z_{d} \cdot F_{c}\right) / F_{a} .
$$

The equation is used for systems that provide all or part of the ventilation by recirculating air from other zones without directly blending them with the outside air. 
The effectiveness of the ventilation system is determined from the equation:

$$
E_{v}=\min \left(E_{v z}\right) .
$$

In equation (13) $F_{a}$ is the proportion of the inflow air in the zone from sources outside the zone:

$$
F_{a}=E_{p}+\left(1-E_{p}\right) \cdot E_{r} ;
$$

$F_{b}$ - fraction of the inflow air in the zone of completely mixed primary air:

$$
F_{b}=E_{p} ;
$$

$F_{c}$ - share of external air in the zone from sources outside the zone:

$$
F_{c}=1-\left(1-E_{z}\right) \cdot\left(1-E_{r}\right) \cdot\left(1-E_{p}\right) ;
$$

$E_{p}-$ share of primary air in the zone:

$$
E_{p}=V_{p z} / V_{d z},
$$

$\left(E_{p}=1.0\right.$ for single-channel and single-zone systems); $E_{r}$ - systems with repeated recirculation reverse air, share of air recirculation in the area, which represents the average reverse air system, not specifically taken from the area, generally, $E_{r}=0.0 ; E_{z}$ - efficiency of zonal air supply, is determined from Table 1; $V_{d z}$ - total air flow, (1/s); $V_{p z}$ - initial zonal air flow rate $1 / \mathrm{s} ; X_{s}$ - the average value of the ventilation component: in the initial treatment of air, the proportion of external air in the initial air flow,

$$
X_{s}=V_{\text {ou }} / V_{p s}
$$

$Z_{d}$ - maximum value of the ventilation component: the proportion of external air required for air supplied to the zone,

$$
Z_{d}=V_{o z} / V_{d z}
$$

$V_{o z}$ - zonal air flow: estimated outside air flow, required for the zone, i.e.:

$$
V_{o z}=V_{b z} / E_{z} .
$$

Thus, both for single-channel systems, and in the general case, the zonal air flow required for ventilation of the zone depends on the air supply and removal scheme (see Table 1) from the premise, that is the organization of air exchange. However, the recommended schemes in the ASHRAE standard (Table 1) do not cover the entire variety of indoor air supply and removal schemes. The effectiveness of ventilation depends not only on the scheme of organization of air exchange, but also on the type and location of sources of pollution in the room, the presence of moving objects, etc.

\section{CONCLUSIONS}

Energy efficiency of ventilation and air conditioning systems is determined by the scheme of organization of air exchange, type, location and power sources of pollution, technological processes, structural features of the premises, air distribution system, etc. The methods for determining the criteria for the effectiveness of ventilation systems in the post-Soviet, European and American approaches are rather simplistic, not taking into account the influence of all the above factors on the state of the air environment in the premises. It is not possible to determine the intensity of turbulence according to the existing methods, the value of which is normalized. Therefore, it is necessary to develop a criterion for assessing the effectiveness of ventilation, which takes into account the majority of factors that affect the microclimate in the room, and have explicit physical content. 
Table 1. Efficiency of air distribution in zones

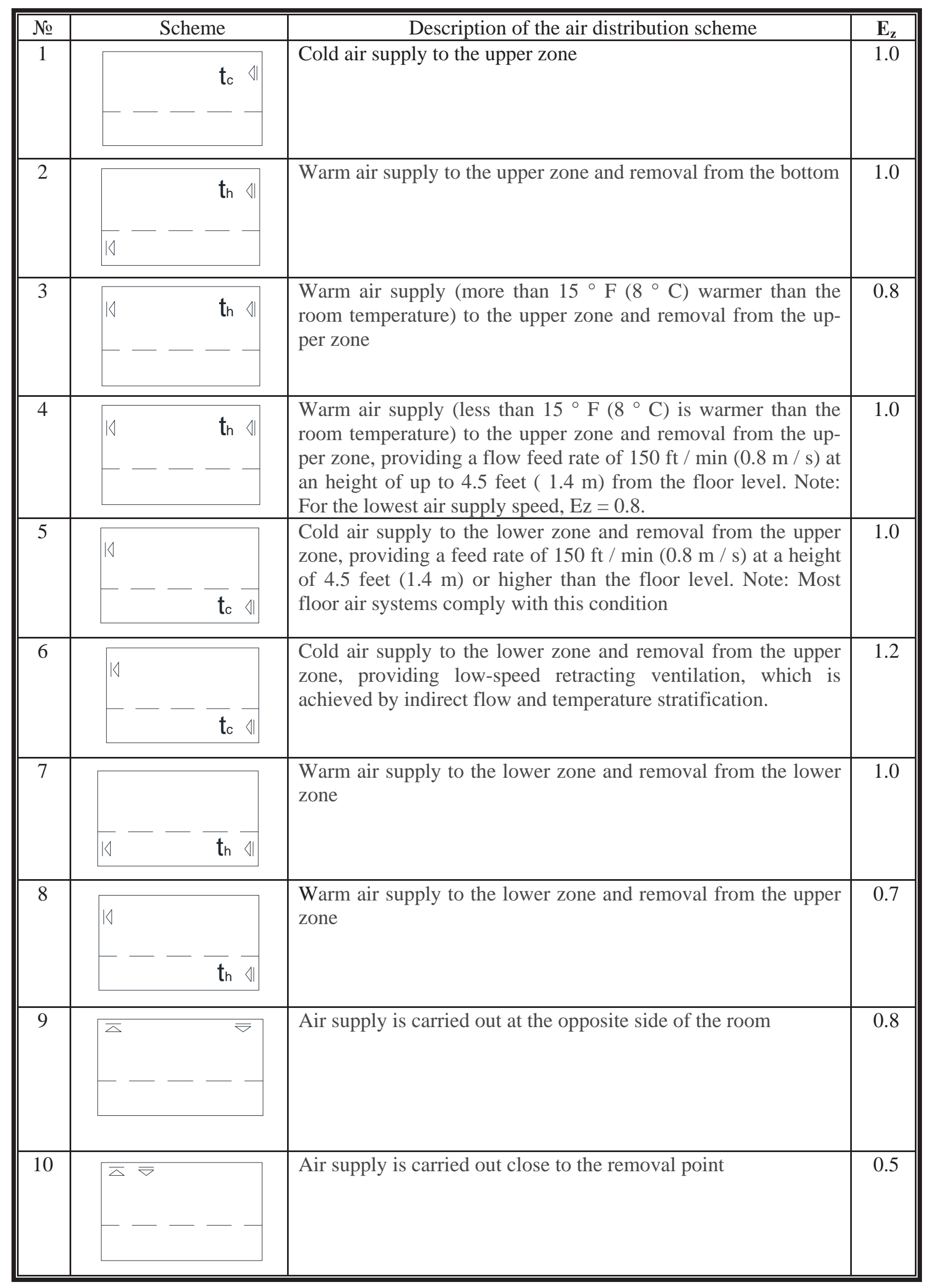




\section{REFERENCES}

1. Pozin G. M. (2011). O tochnosti opredelenija kojefficienta vozduhoobmena [On the accuracy of determining the air exchange coefficient]. Vestnik MGSU. Moskva, 7, 319-325 (in Russian).

2. Grimitlin M. I., Moor L. F., Pozin G. M. (1992). Organizacija vozduhoobmena i raspredelenie vozduha $\mathrm{v}$ pomeshhenijah. Vnutrennie sanitarno-tehnicheskie ustrojstva [Organization of air exchange and distribution of air in premises. Internal sanitary-technical devices]. Ventiljacija i kondicionirovanie vozduha (Spravochnik proektirovshhika). CH.3. G.17. Moskva : Strojizdat, 114-150 (in Russian).

3. Dovgaljuk V. B., Milejkovs'kij V. O. (2007). Efektivnist' organizacii povitroobminu $\mathrm{v}$ teplo napruzhenih primishennjah u stisnutih umovah [Efficiency of organization of air exchange in heat-intensive premises in compressed conditions]. Budivnictvo Ukraini : Naukovo-virobnichij zhurnal 3, 36-39 (in Ukrainian).

4. El'terman V.M. (1980). Ventiljacija himicheskih proizvodstv [Ventilation of chemical industries]. Moskva : Himija, 288 (in Russian).

5. Uspenskaja L. B. (1970). Zakonomirnost rozpodilu povitrja u ventiljuєmih primishhennjah [Patterns of air distribution in ventilated areas]. Voprosy proektirovanija i montazha sanitarnotehnicheskih sistem. VNIIGM. Vyp.30. Moskva : strojizdat (in Russian).

6. ANSI/ASHRAE Standard 62-2016 Ventilation for Acceptable Indoor Air Quality

7. CSN EN 13779 Ventilation for non-residential buildings - Performance requirements for ventilation and room-conditioning systems

8. Sorokin N.S. (1965). Ventiljacija, otoplenie i kondicionirovanie vozduha na tekstil'nyh fabrikah [Ventilation, heating and air conditioning in textile factories]. Legkaja industrija, 342 (in Russian).

9. Pozin G. M., Sost. (1983). Opredelenie kolichestva pritochnogo vozduha dlja proizvodstvennyh pomeshhenij s mehanicheskoj ventiljaciej: Metodicheskie rekomendacii [Determination of the amount of air supply for industrial premises with mechanical ventilation: Methodical recommendations]. L. : VNIIOT VCSPS, 57 (in Russian).

10.Pozin G. M. (1975). Principy analiticheskogo opredelenija kojefficientov vozduhoobmena [Principles of analytical determination of air exchange coefficients]. Issledovanie razlichnyh sposobov vozduhoobmena $v$ proizvodstvennyh pomeshhenijah. Moskva, 43-53 (in Russian).
11.Pozin G. M. (2012). Novyj podhod k ocenke jeffektivnosti vozduhoobmena [A new approach to the assessment of air exchange efficiency]. Sovremennye problemy nauki i obrazovanija. № 4. (in Russian).

12. Cao G. Y., Sirén K., Kilpeläinen S. (2014). Modelling and experimental study of performance of the protected occupied zone ventilation. Energy Build; 68:515e31.

13.Seppänen O. (2008). Ventilation strategies for good indoor air quality and energy efficiency. Int J Vent; 6(4):297e306.

14. Sotnikov A. G. (1976). Sistemy kondicionirovanija s kolichestvennym regulirovaniem [Conditioning systems with quantitative regulation]. Strojizdat, Leningrad. 168 (in Russian).

15. Cho YJ, Hazim B, Awbi HB, Karimipanah T. (2008). Theoretical and experimental investigation of wall confluent jets ventilation and comparison with wall displacement ventilation. Build Environ;43:1091e100.

16. Karimipanah T, Awbi H. B. (2002). Theoretical and experimental investigation of impinging jet ventilation and comparison with wall displacement ventilation. Build Environ;37:1329e42.

17.Awbi HB (2008). Ventilation systems e design and performance. Taylor \& Francis;

18.EN 15242 (2007). Ventilation for buldingcalculation methods for determination of air flow rates in buildings including infiltration. Brussels : CEN, 54

19.Brelih N. (Editor), Seppanen O., Berthilsson T., Maripun M. L., Lamy H., Borre A. V. (2012). Design of energy efficient ventilation and air conditioning systems. REHVA Guidebook N17. Brusells: REHVA, 102p.

20.Sandberg M. (1981). What is ventilation efficiency? Build Environ;16:123e35.

21.Potter I. N. (1988). Ventilation effectiveness in mechanical ventilation systems. Technical Note 1/8, ISBN $086022189 \mathrm{X}$;.

22.Skistad H., Bronsema B. (2004). Ventilation and smoking e reducing the exposure to. ETS in buildings. Federation of European Heating and Airconditioning Association REHVA;.

23.Sandberg M., Blomqvist C., Sjöberg M. (1986). Efficiency of general ventilation systems in residential and office buildings e concepts and measurements. In: Goodfellow HD, editor. Ventilation 85. Elsevier Science Publishers B.V Amsterdam e Printed in The Netherlands.

24.Awbi HB., Gan G. (1993). Evaluation of the overall performance of room air distribution. In: Proceedings of indoor air, vol. 3. P. $283 \mathrm{e} 8$. 


\section{Аналіз методів оцінки ефективності організації повітрообміну}

\section{Володимир Довгалюк, Анна Ситницька, Микола Терещук}

Анотація. Наведено огляд наукової літератури по оцінці методів ефективності систем вентицяції. Показано, що вимоги до енергоефективності систем забезперчення мікроклімату будівель набувають все більшого значення. На деяких будівлях експлуатаційні витрати на системи вентиляції та кондиціонування повітря можуть досягати 50\% від загальних витрат. Стан повітряного середовища безпосередньо впливає на здоров'я людей та продуктивність їх праці. Тому актуальним $є$ питання оцінки якості систем вентиляції та кондиціонування повітря на етапі проектування. Існують різні підходи до визначення критерія ефективності повітрообміну у приміщенні. Сучасні підходи до оцінки ефективності вентиляції в Україні, країнах ЕС та США значно відрізняються, що потребує аналізу та розуміння переваг і недоліків кожного 3 них. Оцінка ефективності повітрообміну 3 використанням коефіцієнта $K_{L}$ базується на побудові наближеної математичної моделі тепломасообмінних процесів у приміщенні. Розроблено методи його аналітичного визначення.
Однак, коефіцієнт $K_{L}$ не дозволяє оцінити ефективність систем вентиляції зі змінною витратою повітря, проблематичним $є$ використання $K_{L}$ при рівномірному розподілу температури у приміщенні за висотою. Свропейський підходи до оцінки до оцінки ефективності вентиляції базуються на оцінці концентрації $\mathrm{CO} 2$ в середньому по приміщенню або середній концентрації $\mathrm{CO} 2$ в зоні обслуговування. Використовується також концепція «віку» повітря. Оцінити ефективність вентиляції по формуванню температурних і вологістних полів у приміщенні по європейським методикам, неможливо. Стандарти США використовують оцінку якості повітря у приміщенні та споживанні енергії для порівняння ефективності вентиляції $E_{v z}$. Однак, визначення ефективності повітророзподілення $E_{z}$, від якого залежить величина $E_{v z}$, здійснюється по спрощеній методиці. Всі існуючі методики не дозволяють визначити інтенсивність турбулентності повітря у приміщенні. Виникає необхідність розробки критерія оцінки ефективності вентиляції, який враховує більшість факторів, які впливають на стан мікроклімату у приміщенні.

Ключові слова. Енергоефективність, системи вентиляції, кондиціонування, коефіцієнт, витрата, "вік" повітря, американська методологія, VAV-системи, одноканальні системи, подача холодного повітря. 